\title{
Study of Clinical Profile of Community-acquired Pneumonia with Special Reference to C-reactive Protein and Procalcitonin Levels
}

\author{
${ }^{1}$ KC Prajwal, ${ }^{2} \mathrm{MV}$ Krishna, ${ }^{3}$ Sharanappa Patil
}

\begin{abstract}
Introduction: Pneumonia is defined as an infection of the pulmonary parenchyma. Despite being the cause of significant complications and deaths, pneumonia is often wrongly diagnosed, mistreated, and underestimated. The incidence rates are highest in old-aged patients. In the current prospective observational study, we intend to study the utility of procalcitonin (PCT) level and serum C-reactive protein (CRP) level for diagnosing pneumonia.

Design: Prospective observational studies.

Materials and methods: The study was conducted in RajaRajeswari Medical College and Hospital, Bengaluru, during the period extending from June to May 2014. Eighty patients, aged more than 18 years, with diagnosis of pneumonia were included in the study. Serum PCT levels were calculated using BRAHMS PCT Kryptor immunofluorescent assay (Biomerieux, France). Other routine investigations, including CRP, sputum culture, and endotracheal secretions cultures, were done. Chisquare analysis was done to assess its prognostic and diagnostic significance. Data were analysed with Statistical Package for the Social Sciences (version 17.0 for Windows).
\end{abstract}

Results and conclusion: C-reactive protein was positive in $60(75 \%)$ of the patients, and PCT was positive in $45(56.25 \%)$ patients; 28 patients had PCT levels 0.5 to $1.5 \mathrm{ng} / \mathrm{mL}, 1(3.6 \%)$ had CRP $<6 \mathrm{mg} / \mathrm{mL}, 27$ (96.4\%) had CRP $>6 \mathrm{mg} / \mathrm{mL}$; 17 patients had PCT values $>1.5 \mathrm{ng} / \mathrm{mL}$ and CRP was positive in all patients $(p<0.001)$. Streptococcus pneumonia was the most common and isolated in $8(10 \%)$ patients. C-reactive protein is a useful and better adjuvant in the diagnosis of community-acquired pneumonia (CAP). Positive PCT levels indicate a bacterial etiology for pneumonia. A high PCT level is a poor prognostic indicator and is associated with a higher mortality.

Keywords: Biomarker, Pneumonia, Procalcitonin, Prognosis, Prohormone.

How to cite this article: Prajwal KC, Krishna MV, Patil S. Study of Clinical Profile of Community-acquired Pneumonia with Special Reference to C-reactive Protein and Procalcitonin Levels. J Med Sci 2016;2(2):27-30.

Source of support: Nil

Conflict of interest: None

${ }^{1}$ Assistant Professor, ${ }^{2}$ Professor and Head, ${ }^{3}$ Postgraduate Student

${ }^{1-3}$ Department of General Medicine, RajaRajeswari Medical College and Hospital, Bengaluru, Karnataka, India

Corresponding Author: KC Prajwal, Assistant Professor Department of General Medicine, RajaRajeswari Medical College and Hospital, Bengaluru, Karnataka, India, e-mail: prajwal.999@gmail.com

\section{INTRODUCTION}

The Infectious Diseases Society of America (IDSA) defines community-acquired pneumonia (CAP) as "an acute infection of the pulmonary parenchyma, i.e., associated with at least some symptoms of acute infection, accompanied by the presence of an acute infiltrate on a chest radiograph or auscultatory findings consistent with pneumonia (such as altered breath sounds and or localized rales), in a patient not hospitalized or residing in a long-term care facility for more than 14 days before onset of symptoms." ${ }^{1}$

A rapid diagnosis of pneumonia and an accurate differentiation from viral respiratory illnesses and noninfectious causes have important therapeutic and prognostic implications. In the current prospective observational study, we intended to study the utility of procalcitonin (PCT) level in comparison with C-reactive protein (CRP) in the diagnosis and prognosis of pneumonia.

\section{Procalcitonin in Community-acquired Pneumonia}

In patients with CAP, improved diagnostic assessment by PCT is important in order to differentiate from other noninfectious infiltrates and to guide the duration of antibiotics.

The dynamics of PCT levels have prognostic implications, as persistently elevated levels are associated with adverse outcome. Conversely, decreasing PCT levels suggest a favorable outcome, usually showing a log-linear drop-off and a half-life of 20 to 24 hours. The prognostic accuracy of PCT in the ICU can be markedly improved by considering the course of PCT. Mortality increased with every day that PCT increased.

\section{C-reactive Protein}

C-reactive protein was first described by Tillett and Frances in 1930, as a serum component present in acutely ill patients that reacted with a specific Streptococcus pneumoniae extract and they termed Fraction $\mathrm{C}^{2} \mathrm{C}$-reactive protein is the prototypical acute phase protein in humans and is an important mediator of host defense. Normal baseline levels of circulating CRP are low, but increase up to 10,000-fold within hours of inflammation induced 
by infection or injury. It binds a wide array of extrinsic (bacteria, fungus, parasite, and plant components) and intrinsic (damaged cell membranes, chromatin, histones, and apoptotic cells) ligands, and subsequently activates the classical complement pathway and binds immunoglobulin receptors on phagocytes.

C-reactive protein has recently received increased attention as numerous studies have implicated it as a predictive biomarker for cardiovascular disease risk. ${ }^{3}$ However, because CRP is a nonspecific indicator of inflammation, its levels can be significantly influenced by a number of disease conditions as well as other parameters. Normal concentration in healthy human serum is usually lower than $10 \mathrm{mg} / \mathrm{L}$, slightly increasing with aging. Higher levels are found in late pregnant women, mild inflammation and viral infections (10-40 mg/L), active inflammation, bacterial infection (40-200 mg/L), and severe bacterial infections and burns (>200 mg/L).

\section{MATERIALS AND METHODS}

\section{Source of Data}

Eighty patients, aged more than 18 years, admitted to RajaRajeswari Medical College and Hospital (RRMCH), Bengaluru, with the diagnosis of pneumonia from June 14 to May 15, were included in the study.

\section{Methods of Collection of Data}

Patients satisfying the inclusion criteria and admitted in the Department of Internal Medicine and Department of Pulmonology in RRMCH, Bengaluru were included in the study. This study enrolled 80 patients with CAP, above 18 years of age. Data was collected in a proforma.

Routine hemogram with hematocrit, routine urine analysis, renal function tests, random blood sugar, liver function tests, serum electrolytes, chest X-ray, sputum Gram's stain, sputum culture, sputum acid-fast bacilli, blood culture, CRP, and serum PCT were investigated for all patients. The proposed study is a prospective observational study and appropriate statistical analysis is carried out.

\section{Inclusion Criteria}

Consecutive patients of CAP, in medicine and pulmonology ward of RRMCH.

\section{Exclusion Criteria}

- Patients having upper respiratory tract infections

- Patients having pulmonary tuberculosis

- Patients having lung abscess patients

- Patients less than 18 years

- Hepatic failure patients
- Renal failure patients

- Congestive cardiac failure.

\section{PROCALCITONIN TEST PROCEDURE}

\section{Methods}

Chemiluminescence assay [immunoluminometric assay (ILMA)]: For the PCT assay, tubes were coated with a monoclonal antibody specific for the katacalcin part of PCT. This antibody binds to amino acids 102 to 111 of PCT. Coating of the antibody was done for 20 hours on polystyrene tubes $(2.0 \mu \mathrm{g} /$ tube $)$ in $0.3 \mathrm{~mL}$ of buffer $(10 \mathrm{mmol} / \mathrm{L}$ Tris-HCl, pH 7.8, 10 mmol/L NaCl). Tubes were blocked with $10 \mathrm{mmol} / \mathrm{L}$ sodium phosphate buffer containing $30 \mathrm{q} / \mathrm{L}$ Karion FP, $5 \mathrm{gm} / \mathrm{L}$ protease-free bovine serum albumin (Sigma), pH 6.8, and lyophilized. A polyclonal sheep antibody specific for the calcitonin part of PCT was used as tracer. This antibody was raised to peptide 69 to 79 (GTYTQDLNKFH) of PCT and was affinity-purified on a calcitonin-sulfo link column and subsequently labeled with acridinium ester as follows: $100 \mu \mathrm{g}$ of antibody in $20 \mathrm{mmol} / \mathrm{L}$ sodium phosphate buffer, $\mathrm{pH}$ 8.0, was incubated for 20 minutes at room temperature with $10 \mu \mathrm{L}$ of acridinium ester ( $1 \mathrm{gm} / \mathrm{L}$ in acetonitrile; Hoechst AG). Labeled antibody was purified by high performance liquid chromatography (HPLC) using a Knauer hydroxyapatite column (buffer gradient, 1-500 mmol/L potassium phosphate, $\mathrm{pH}$ 6.8; flow rate, $0.8 \mathrm{~mL} / \mathrm{min}$ ). Procalcitonin was measured in a coated tube assay in which $100 \mu \mathrm{L}$ of a patient sample or calibrator was added in duplicate to each antibody-coated tube and incubated for 30 minutes at room temperature; $200 \mu \mathrm{L}$ of tracer containing acridinium ester-labeled anti-PCT antibody was then added, followed by a 2-hour incubation at room temperature. Tubes were washed five times with $2 \mathrm{~mL}$ of standard LUMI test ${ }^{\circledR}$ washing buffer (B_R_A_H_M_S AG), and detection was performed in a luminometer (detection time per sample, 1 second). This assay system was named LUMI test PCT ${ }^{\circledR}$ (B_R_A_H_M_S AG). Relative light units for the chemiluminescence assay were expressed in $\mathrm{ng} / \mathrm{L}$. Procalcitonin is calculated from a calibration curve that was included in every analytical run. The PCT concentrations $<0.5 \mathrm{ng} / \mathrm{mL}$ are negative. ${ }^{5-8}$

\section{RESULTS}

The results are tabulated in Tables 1 to 4 .

Table 1: C-reactive protein $\mathrm{mg} / \mathrm{L}$ normal $<6 \mathrm{mg} / \mathrm{L}$

\begin{tabular}{llll}
\hline \multirow{2}{*}{$\begin{array}{c}\text { C-reactive protein } \\
m g / L \text { normal }<6 \text { mg/L }\end{array}$} & \multicolumn{2}{c}{ Gender } & \\
\cline { 2 - 3 } & Female & Male & Total \\
\hline$<6$ & $12(29.3 \%)$ & $8(20.5 \%)$ & $20(25 \%)$ \\
$>6$ & $29(70.7 \%)$ & $31(79.5 \%)$ & $60(75 \%)$ \\
\hline Total & $41(100 \%)$ & $39(100 \%)$ & $80(100 \%)$ \\
\hline
\end{tabular}


Study of Clinical Profile of Community-acquired Pneumonia with Special Reference to CRP and PCT Levels

Table 2: Procalcitonin $(\mathrm{ng} / \mathrm{mL})$ normal $<0.5 \mathrm{ng} / \mathrm{mL}$

\begin{tabular}{clll}
\hline $\begin{array}{l}\text { Procalcitonin }(\mathrm{ng} / \mathrm{mL}) \\
\text { normal }<0.5 \mathrm{ng} / \mathrm{mL}\end{array}$ & Female & Male & Total \\
\hline$<0.5$ & $22(53.7 \%)$ & $13(33.3 \%)$ & $35(43.8 \%)$ \\
$0.5-1.5$ & $10(24.4 \%)$ & $18(46.2 \%)$ & $28(35 \%)$ \\
$>1.5$ & $9(22 \%)$ & $8(20.5 \%)$ & $17(21.3 \%)$ \\
\hline
\end{tabular}

\section{DISCUSSION}

We studied a total of 80 patients of CAP. In our study the age of patients presenting with CAP ranged from 18 to 70 years and above. Of these $23(28 \%)$ were between 51 and 60 years, $19(23.8 \%)$ were between 61 and 70 years, $5(6.3 \%)$ were above 70 years; mean \pm SD: $52.21 \pm 15.04$.

In our study of 80 patients, 60 (75\%) patients had positive CRP $>6 \mathrm{mg} / \mathrm{L}$, 29 were females, and 31 were males (Table 1). The mean age of the patients whose CRP was positive and is $>6 \mathrm{mg} / \mathrm{L}$ is 50 to 60 years \pm 10 years $(\mathrm{p}=0.935)$.

In another study conducted by the Flanders et al they reported on a small subgroup of patients with pneumonia who had CRP of $<11 \mathrm{mg} / \mathrm{mL}$. In 54 patients with pneumonia with low CRP in our study, the estimated diagnostic risk of pneumonia was high $(\mathrm{n}=3)$ or intermediate $(n=51)$ based on the history and the physical examination results as defined in our model. These findings emphasize that CRP test results should be interpreted together with clinical findings. ${ }^{9}$

We estimated PCT in the same above 80 patients on the day of admission; 35 (43.8\%) had negative PCT $<0.5 \mathrm{ng} / \mathrm{mL}, 28$ (35\%) had PCT 0.5 to $1.5 \mathrm{ng} / \mathrm{mL}$, and $17(21.3 \%)$ had PCT $>1.5 \mathrm{ng} / \mathrm{mL}$. In a similar study done by Huang et al, ${ }^{10}$ (Tables 2 and 3) patients presenting with a clinical and radiographic diagnosis of CAP were enrolled, and stratified a priori according to PCT levels into four tiers - I: $<0.1$; II: $\geq 0.1$ to $<0.25$; III: $\geq 0.25$ to $<0.5$; and IV: $\geq 0.5 \mathrm{ng} / \mathrm{mL}$. Primary outcome was 30 -day mortality and 1,651 patients formed the study cohort. The mean PCT level at presentation was $3.4 \mathrm{ng} / \mathrm{mL}$, but levels were broadly spread, such that 542 subjects $(32.8 \%)$ were in tier I, $356(21.6 \%)$ in tier II, $169(10.2 \%)$ in tier III, and $584(35.4 \%)$ in tier IV. Masiá et al ${ }^{11}$ studied 185 patients of CAP from October 15, 1999 to October 14, 2000. The mean PCT at admission was $0.49 \mathrm{ng} / \mathrm{mL}$. In another study in patients with CAP done by Holm et $\mathrm{al}_{1}{ }^{12} 70 \%$ patients of a total of 48 had a positive PCT. Müller et $\mathrm{al}^{13}$ conducted a study in Switzerland in which 373 patients of CAP had a mean PCT of 3.1 at admission.

Boussekey et $\mathrm{al}^{14}$ in August 2005 did a study to determine the diagnostic and prognostic role of PCT in patients admitted in an intensive care unit for severe CAP. Moreover, 110 patients hospitalized in ICU were prospectively studied. Within 48 hours following ICU admission, the PCT serum level was measured with a quantitative
Table 3: Gender distribution of patients studied with PCT levels

\begin{tabular}{lllll}
\hline & \multicolumn{3}{c}{ Procalcitonin } & \\
\cline { 2 - 4 } Gender & $<0.5$ & $0.5-1.5$ & $>1.5$ & Total \\
\hline Female & $22(62.9 \%)$ & $10(35.7 \%)$ & $9(52.9 \%)$ & $41(51.3 \%)$ \\
Male & $13(37.1 \%)$ & $18(64.3 \%)$ & $8(47.1 \%)$ & $39(48.8 \%)$ \\
\hline Total & $35(100 \%)$ & $28(100 \%)$ & $17(100 \%)$ & $80(100 \%)$ \\
\hline$p=0.100$, Not significant, Chi-square test &
\end{tabular}

method above a threshold value of $0.5 \mathrm{ng} / \mathrm{mL} .20 \%$ of the patients had a serum PCT level $<0.5 \mathrm{ng} / \mathrm{mL}, 30 \%$ between $0.5 \mathrm{ng} / \mathrm{mL}$ and $2 \mathrm{ng} / \mathrm{mL}$, and $50 \% \geq 2 \mathrm{ng} / \mathrm{mL}$.

Hedlund and Hansson ${ }^{15}$ studied 96 patients, 50 to 85 years of age, treated in the hospital for CAP. On admission, 60 patients (54\%) had elevated PCT levels $(>0.1 \mu \mathrm{g} / \mathrm{L})$. In our study, the age wise distribution of PCT showed PCT value of $>1.5 \mathrm{ng} / \mathrm{mL}$ seen evenly in all age group between 20 and 70 years, whereas the mean age of the patient was 50 to $60 \pm 10$ years that showed PCT value of 0.5 to $1.5 \mathrm{ng} / \mathrm{mL}$. In the study done by Huang et al, the mean age was 65 years. In the Masiá et al study, the mean age of patients with PCT $<0.5 \mathrm{ng} / \mathrm{mL}$ was 64 years. The mean age of patients with PCT $>0.5 \mathrm{ng} / \mathrm{mL}$ patients was 73 years. In the study done by Müller et al, the mean age was $67 \pm 18$ years. In the study by Krüger et $\mathrm{al}_{1}^{16}$ the mean $\pm \mathrm{SD}$ (range) age was $61 \pm 18$ (18-98) years.

The PCT was positive in $26(57.7 \%)$ male patients, and $19(42.2 \%)$ female patients. In other studies done by Huang et al, Masiá et al, Müller et al, and Hedlund and Hansson mentioned above, the percentage of males was $52,63,63$, and $48 \%$ respectively. A study done by Krüger et $a{ }^{16}$ comprised 1,671 patients of CAP. Approximately $55 \%$ were males.

In our study of 35 patients PCT $<0.5 \mathrm{ng} / \mathrm{mL}$, out of which 19 (54.3\%) had CRP $<6 \mathrm{mg} / \mathrm{mL}, 16$ (45.7\%) had CRP $>6 \mathrm{mg} / \mathrm{mL}$. A total of 28 patients had PCT 0.5 to $1.5 \mathrm{ng} / \mathrm{mL}$, 1(3.6\%) had CRP $<6 \mathrm{mg} / \mathrm{mL}, 27(96.4 \%)$ had CRP $>6 \mathrm{mg} / \mathrm{mL}$. Moreover, 17 patients had PCT values $>1.5 \mathrm{ng} / \mathrm{mL}$ and CRP was positive in all patients $(\mathrm{p}<0.001)$ Table 4 . In our study, 16 patients had CRP $>6 \mathrm{mg} / \mathrm{mL}$ and PCT $<0.5 \mathrm{ng} / \mathrm{mL}$. This can be explained by the increased incidence of the viral pneumonia (h1n1) during the study period. Thus, this study was helpful in distinguishing the viral and bacterial pneumonia as PCT is positive only in bacterial pneumonia.

Table 4: C-reactive protein in association with PCT levels

\begin{tabular}{cllll}
\hline & \multicolumn{3}{c}{ Procalcitonin } & \\
\cline { 2 - 4 } CRP & $<0.5$ & $0.5-1.5$ & $>1.5$ & Total \\
\hline$<6 \mathrm{mg} / \mathrm{L}$ & $19(54.3 \%)$ & $1(3.6 \%)$ & $0(0 \%)$ & $20(25 \%)$ \\
$>6 \mathrm{mg} / \mathrm{L}$ & $16(45.7 \%)$ & $27(96.4 \%)$ & $17(100 \%)$ & $60(75 \%)$ \\
\hline Total & $35(100 \%)$ & $28(100 \%)$ & $17(100 \%)$ & $80(100 \%)$ \\
\hline \multicolumn{2}{c}{$\mathrm{p}<0.001^{* *}$, Significant, Chi-square test }
\end{tabular}




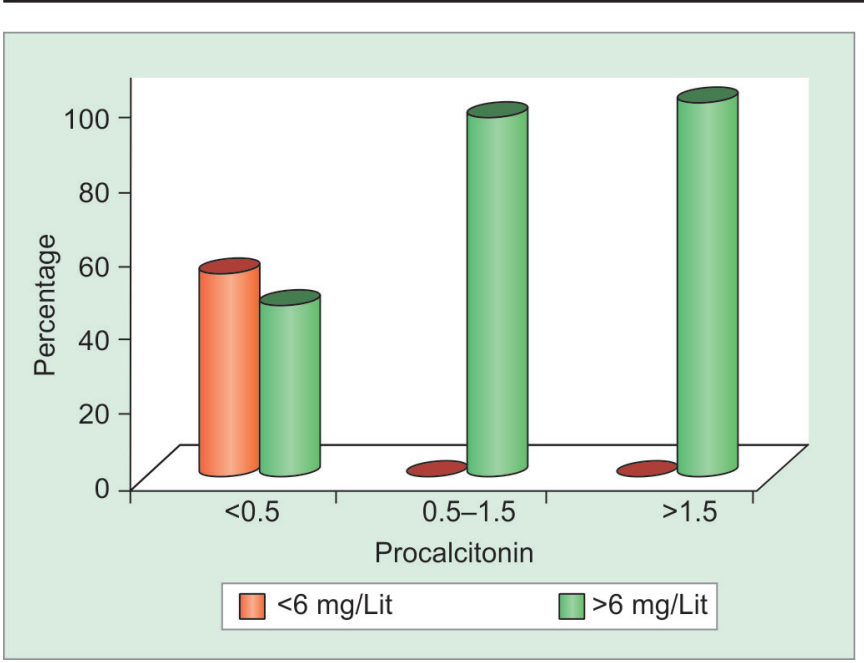

Graph 1: C-reactive protein and PCT correlation

In a prospective study done by Luzzani et al, ${ }^{17}$ the linear correlation between PCT plasma concentrations and the four categories of patients (sepsis negative, SIRS, localized infection, and sepsis group) was much stronger than in the case of CRP (Spearman's rho, 0.73 vs 0.41 ; $p<0.05$ ). A rise in sepsis-related organ failure assessment score was related to a higher median value of PCT but not CRP. They concluded that PCT is a better marker of sepsis than CRP and course of PCT shows a closer correlation than that of CRP with the severity of infection and organ dysfunction. Results of our study match with these findings (Graph 1).

In another study conducted by van Vugt et $\mathrm{al}^{18}$ showed the measurement of PCT added no relevant additional diagnostic information. A simplified diagnostic score based on symptoms signs, and CRP $>30 \mathrm{mg} / \mathrm{mL}$ resulted in proportions of the pneumonia of $0.7,3.8$, and $18.2 \%$ in the low, intermediate, and high-risk group respectively.

\section{CONCLUSION}

- C-reactive protein and PCT were positive in all age groups, but more positive in the age group of 40 to 70 years.

- C-reactive protein and PCT were uniformly positive in males and females.

- Majority of the patients with CAP had CRP positive (75\%) than compared with PCT (56.3\%).

- There was a linear correlation between PCT and CRP in patients with CAP; CRP was positive in all patients whose PCT was positive $(\mathrm{p}<0.001)$.

\section{REFERENCES}

1. Bartlett JG, Dowell SF, Mandell LA, File TM Jr, Musher DM, Fine MJ. Practice guidelines for the management of communityacquired pneumonia in adults. Infectious Diseases Society of America. Clin Infect Dis 2000 Aug;31(2):347-382.

2. Tillett WS, Francis T. Serological reactions in pneumonia with a non-protein somatic fraction of pneumococcus. J Exp Med 1930 Sep;52(4):561-571.
3. Frank R, Hargreaves R. Clinical biomarkers in drug discovery and development. Nat Rev Drug Discov 2003 Jul;2(7):566-580.

4. Clyne B, Olshaker JS. The C-reactive protein. J Emerg Med 1999 Nov-Dec;17(6):1019-1025.

5. Müller B, Becker KL, Schächinger H, Rickenbacher PR, Huber PR, Zimmerli W, Ritz R. Calcitonin precursors are reliable markers of sepsis in a medical intensive care unit. Crit Care Med 2000 Apr;28(4):977-983.

6. Harbarth S, Holeckova K, Froidevaux C, Pittet D, Ricou B, Grau GE, Vadas L, Pugin J. Geneva Sepsis Network. Diagnostic value of procalcitonin, interleukin-6, and interleukin-8 in critically ill patients admitted with suspected sepsis. Am J Respir Crit Care Med 2001 Aug;164(3):396-402.

7. Brunkhorst FM, Wegscheider K, Forycki ZF, Brunkhorst R. Procalcitonin for early diagnosis and differentiation of SIRS, sepsis, severe sepsis, and septic shock. Intensive Care Med 2000 Mar;26 (Suppl 2):S148-S152.

8. Mathis G., Clin. Chem. 1993; 39:1953-1959.

9. Flanders SA, Stein J, Shochat G, Sellers k, Holland M, Maselli J, Drew WL, Reingold AL, Gonzales R. Performance of bedside $C$ reactive protein test in the diagnosis of community acquired pneumonia in adults with cough. Am J Med 2004 Apr;116(8):529-535.

10. Huang DT, Weissfeld LA, Kellum JA, Yealy DM, Kong L, Martino M, Angus DC, GenIMS Investigators. Risk prediction with procalcitonin and clinical rules in communityacquired pneumonia. Ann Emerg Med 2008 Jul;52(1):48-58.

11. Masiá M, Gutiérrez F, Shum C, Padilla S, Navarro JC, Flores E, Hernández I. Usefulness of procalcitonin levels in community-acquired pneumonia according to the patients outcome research team pneumonia severity index. Chest 2005 Oct;128(4):2223-2229.

12. Holm A, Pedersen SS, Nexoe J, Obel N, Nielsen LP, Koldkjaer O, Pedersen C. Procalcitonin versus C-reactive protein for predicting pneumonia in adults with lower respiratory tract infection in primary care. Br J Gen Pract 2007 Jul;57(540):555-560.

13. Müller B, Harbarth S, Stolz D, Bingisser R, Mueller C, Leuppi J, Nusbaumer C, Tamm M, Christ-Crain M. Diagnostic and prognostic accuracy of clinical and laboratory parameters in community-acquired pneumonia. BMC Infect Dis 2007 Mar;7:10.

14. Boussekey N, Leroy O, Georges H, Devos P, d'Escrivan T, Guery B. Diagnostic and prognostic values of admission procalcitonin levels in community-acquired pneumonia in an intensive care unit. Infection 2005 Aug;33(4):257-263.

15. Hedlund J, Hansson LO. Procalcitonin and C-reactive protein levels in community-acquired pneumonia: correlation with etiology and prognosis. Infection 2000 Mar-Apr;28(2):68-73.

16. Krüger S, Ewig S, Marre R, Papassotiriou J, Richter K, von Baum H, Suttorp N, Welte T, CAPNETZ Study Group. Procalcitonin predicts patients at low risk of death from community-acquired pneumonia across all CRB-65 classes. Eur Respir J 2008 Feb;31(2):349-355.

17. Luzzani A, Polati E, Dorizzi R, Rungatscher A, Pavan R, Merlini A. Comparison of procalcitonin and C-reactive protein as markers of sepsis. Crit Care Med 2003 Jun;31(6):1737-1741.

18. van Vugt SF, Broekhuizen BD, Lammens C, Zuithoff NP, de Jong PA, Coenen S, Ieven M, Butler CC, Goossens H, Little P, et al. Use of serum $\mathrm{C}$ reactive protein and procalcitonin concentrations in addition to symptoms and signs to predict pneumonia in patients presenting to primary care with acute cough: diagnostic study. BMJ 2013 Apr;346:f 2450. 